\title{
Illegal use of natural resources in federal protected areas of the Brazilian Amazon
}

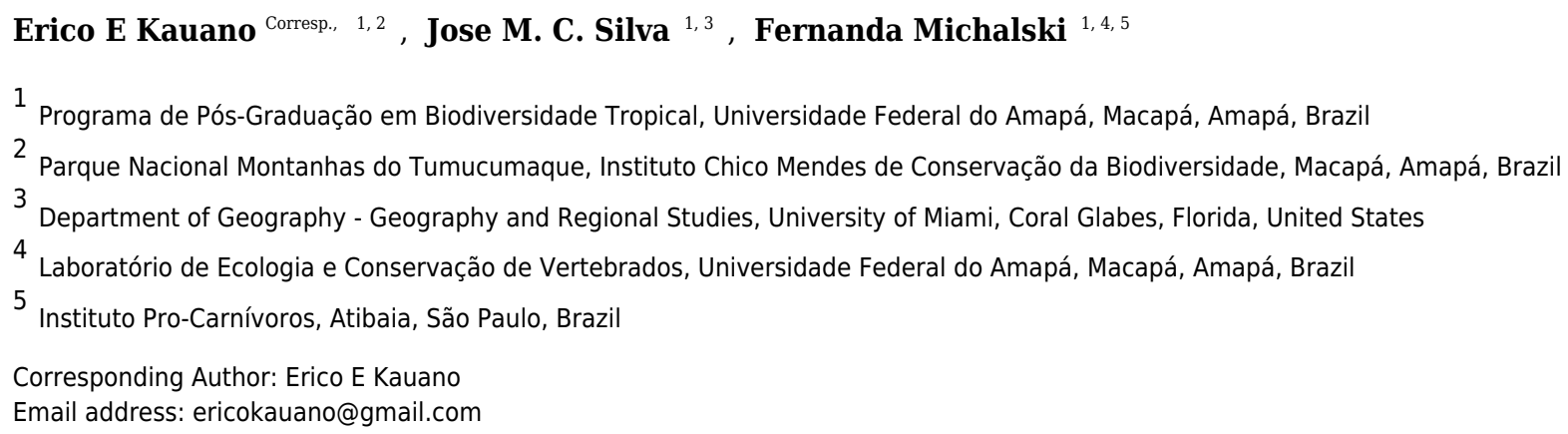

Background. The Brazilian Amazon is the world's largest rainforest regions and plays a key role in biodiversity conservation as well as climate adaptation and mitigation. The government has created a network of protected areas (PAs) to ensure long-term conservation of the region. However, despite the importance of and positive advances in the establishment of PAs, natural resource depletion in the Brazilian Amazon is pervasive. Methods. We evaluated a total of 4,243 official law enforcement records generated between 2010 and 2015 to understand the geographical distribution of the illegal use of resources in federal PAs in the Brazilian Amazon. We classified illegal activities into ten categories and used generalized additive models (GAMs) to evaluate the relationship between illegal use of natural resources inside PAs with management type, age of PAs, population density, and accessibility. Results. We found 27 types of illegal use of natural resources that were grouped into 10 categories of illegal activities. Most infractions were related to suppression and degradation of vegetation (37.40\%), followed by illegal fishing (27.30\%) and hunting activities (18.20\%). The explanatory power of the GAMs was low for all categories of illegal activity, with a maximum explained variation of $41.2 \%$ for illegal activities as a whole, and a minimum of $14.6 \%$ for hunting activities. Discussion. These findings demonstrate that even though PAs are fundamental for nature conservation in the Brazilian Amazon, the pressures and threats posed by human activities include a broad range of illegal uses of natural resources. Population density up to $50 \mathrm{~km}$ from a PA is a key variable, influencing illegal activities. These threats endanger long-term conservation and many efforts are still needed to maintain PAs that are large enough and sufficiently intact to maintain ecosystem functions and protect biodiversity. 
1 Illegal use of natural resources in federal protected areas of the

2 Brazilian Amazon

3 Érico Emed Kauano ${ }^{1,2}$, José Maria Cardoso da Silva ${ }^{1,3}$, Fernanda Michalski ${ }^{1,4,5}$

$4{ }^{1}$ Programa de Pós-Graduação em Biodiversidade Tropical, Universidade Federal do Amapá,

5 Macapá, Amapá, Brazil

$6{ }^{2}$ Parque Nacional Montanhas do Tumucumaque, Instituto Chico Mendes de Conservação da

7 Biodiversidade, Macapá, Amapá, Brazil

$8{ }^{3}$ Department of Geography - Geography and Regional Studies, University of Miami, Coral

9 Glabes, Florida, USA

${ }^{4}$ Laboratório de Ecologia e Conservação de Vertebrados, Universidade Federal do Amapá, Macapá, Amapá, Brazil

${ }^{5}$ Instituto Pro-Carnívoros, Atibaia, São Paulo, Brazil

Corresponding Author:

Érico Kauano ${ }^{1}$

Avenida Dubai 292, Macapá, Amapá, 68906-123, Brazil

Email address: erico.kauano@icmbio.gov.br

17

\section{Abstract}

Background. The Brazilian Amazon is the world's largest rainforest regions and plays a key role in biodiversity conservation as well as climate adaptation and mitigation. The government has created a network of protected areas (PAs) to ensure long-term conservation of the region. However, despite the importance of and positive advances in the establishment of PAs, natural resource depletion in the Brazilian Amazon is pervasive. Methods. We evaluated a total of 4,243 official law enforcement records generated between 2010 and 2015 to understand the geographical distribution of the illegal use of resources in federal PAs in the Brazilian Amazon. We classified illegal activities into ten categories and used generalized additive models (GAMs) to evaluate the relationship between illegal use of natural resources inside PAs with management type, age of PAs, population density, and accessibility. Results. We found 27 types of illegal use of natural resources that were grouped into 10 categories of illegal activities. Most infractions were related to suppression and degradation of vegetation (37.40\%), followed by illegal fishing $(27.30 \%)$ and hunting activities (18.20\%). The explanatory power of the GAMs was low for all categories of illegal activity, with a maximum explained variation of $41.2 \%$ for illegal activities as a whole, and a minimum of $14.6 \%$ for hunting activities. Discussion. These findings demonstrate that even though PAs are fundamental for nature conservation in the Brazilian Amazon, the pressures and threats posed by human activities include a broad range of illegal uses of natural resources. Population density up to $50 \mathrm{~km}$ from a PA is a key variable, influencing illegal activities. These threats endanger long-term conservation and many efforts are still needed to maintain PAs that are large enough and sufficiently intact to maintain ecosystem functions and protect biodiversity. 
40

\section{Introduction}

The Brazilian Amazon is one of the world's largest rainforest regions and plays a key role in biodiversity conservation, maintenance of ecosystem services, and storage of terrestrial carbon stocks (Laurance et al. 2001). In recent years, many advances have been made in combating the widespread and illegal use of the region's natural resources. Political actions based on the establishment of new protected areas (PAs), increases in law enforcement, and support for forestbased economic activities have resulted in a significant deforestation reduction in the region (Fearnside 2005; Nepstad et al. 2009; Silva et al. 2005). In 2010, an extensive network of PAs protected about $54 \%$ of the remaining forests of the Brazilian Amazon and contained around 56\% of its forest carbon (Soares-Filho et al. 2010).

The creation and maintenance of PAs is the most effective way to protect vast areas of tropical forests in the Brazilian Amazon (Dalla-Nora et al. 2014; Soares-Filho et al. 2010; Soares-Filho et al. 2006). Recent studies have indicated that PAs can reduce deforestation and pave the way to a more sustainable use of the region's natural resources (Barber et al. 2012; Nepstad et al. 2014; Nepstad et al. 2006; Nepstad et al. 2009; Pfaff et al. 2015). However, despite all these recent efforts, natural resource degradation in the Brazilian Amazon is still pervasive and thus PAs are subjected to several pressures and threats. Four major factors determine the intensity of pressures on a PA: (a) accessibility; (b) local human population density; (c) management category; and (d) age of the PA.

Accessibility of PAs can be measured by evaluation of navigable rivers and roads that cross or form the boundaries of a given reserve (Peres \& Terborgh 1995). Peres \& Lake (2003) estimate that much of the Amazon basin in Brazil can be accessed on foot from the nearest river or functional road and found that the density of preferred hunted species tended to decrease in areas closer to access points (e.g., roads, rivers). In Amazonia, until 1997, about $90 \%$ of deforestation was concentrated in areas within $100 \mathrm{~km}$ of main roads established by federal government development programs (Alves 2002).

In tropical forests, a positive relationship is observed between the increase in both human population and natural resource extraction, and deforestation (Laurance et al. 2002; Lopez-Carr \& Burgdorfer 2013; Lopez-Carr et al. 2009). However, in the Brazilian Amazon, this relationship is not always positive. While in some regions population density is not a direct cause of deforestation, in others it may be one of the leading causes (Jusys 2016; Tritsch \& Le Tourneau 2016).

The age of the PA (or the time since its creation) is often correlated with better conservation results. Assessments in marine reserves reveal that areas that have been protected for longer show an increase in the quantity and richness of fish species (Claudet et al. 2008; Molloy et al. 2009). However, the relationship of PA age with conservation results may be antagonistic, with some younger PAs in the Brazilian Amazon obtaining better results in relation to reduction or avoidance of deforestation compared with older PAs (Soares-Filho et al. 2010).

The classification of PA classes according to the International Union for Conservation of Nature (IUCN) criteria (Dudley 2008), into strictly protected (I-IV) and sustainable use (or multiple use) management classes (V-VI), has generated several discussions on the efficiency of one category or another in reducing the illegal use of natural resources (Nelson \& Chomitz 2011). While some 
81 experts do not believe in the efficiency of multiple-use PAs in conserving biodiversity in the long

82 term, others believe adoption of this class of PA will lead to a more effective and inclusive

83 conservation strategy (de Toledo et al. 2017; Schwartzman et al. 2010).

Laurance et al. (2012) identified that in addition to the deforestation, across all three tropical continents logging, wildfires, and overharvesting (hunting and harvest of non-timber forest products) are major threats to tropical PA integrity. Many of these threats, unlike deforestation, are difficult to detect (e.g., surface fire, small-scale gold mining, selective logging) or undetectable (e.g., hunting and exploitation of animal products and extraction of non-timber plant products) even with increasingly sophisticated remote sensing techniques (Peres et al. 2006). In this sense, on the ground enforcement activities can result in a wealth of information about the magnitude and types of illegal activities occurring within PAs (Gavin et al. 2010) that are not detected by commonly used remote sensing techniques.

In this study, we evaluated the illegal use of natural resources within 118 federal PAs in the Brazilian Amazon, through the analysis of 4243 illegal activities (infraction records) obtained from law enforcement activities in the period of 2010-2015. First, we categorized illegal activities to determine the main threats found within PAs. Then, we used the infraction records to evaluate the following hypotheses about the intensity of pressures on PAs from illegal activities: (a) fewer illegal activities occur in sustainable use PAs because they have fewer use restrictions than PAs under integral protection; (b) fewer illegal activities occur in older PAs because they have better established administrative structures and management than newer ones; (c) PAs with higher local population density tend to have more illegal activities because of greater anthropogenic pressure; and (d) PAs with greater accessibility tend to have more illegal activities.

\section{Materials \& Methods}

\section{Data sources}

The data used as explanatory variables were obtained from the following publicly available sources: a shapefile describing the geographic boundaries of the Amazon biome from Ministério do Meio Ambiente (MMA 2016); a shapefile describing the geographic boundaries of federal PAs (conservation units) from Instituto Chico Mendes de Conservação da Biodiversidade (ICMBio 2016b); shapefiles describing water bodies (water masses) and rivers (multiscale ottocoded hydrographic base 2013) from Agência Nacional de Águas (ANA 2013); a shapefile describing roads at 1:250000, and limits of Brazil and South America from Instituto Brasileiro de Geografia e Estatística (IBGE) (IBGE/DGC 2015); and shapefiles describing the populational "grid" of Brazil from IBGE (IBGE 2016a).

The data on illegal use of natural resources (illegal activities) used were standardized and made available to authors by the Instituto Chico Mendes de Conservação da Biodiversidade/ Divisão de Informação e Monitoramento Ambiental (ICMBio/DMIF 2017). The maps presented in this study (Fig. 1, Fig. S1, Fig. S2) and area calculations were produced in an equal area projection (Projection: Albers Equal Area Conic; Datum: South America 1969). The geographic information system (GIS) environment was created and the elaboration of spatial variables performed based on geographic data obtained from official sources, in ArcGIS 10.2 software (ESRI 2013). The data on illegal activities compiled and formatted for our study are available in Data S1. 
122

123

124

125

126

127

128

129

130

131

132

133

134

135

136

137

138

139

140

141

142

143

144

145

146

147

148

149

150

151

152

153

154

155

156

157

158

159

160

161

162

\section{Brazilian Amazon}

We delimited the Brazilian Amazon (Fig. 1) according to the boundaries of the Amazonia biome as defined by the Instituto Brasileiro de Geografia e Estatística (IBGE 2004). The IBGE's proposal follows the boundaries laid out in the original extension of the tropical rainforests of northern Brazil (Góes Filho \& Veloso 1982), which is inside the tropical moist broadleaf forests biome (Olson et al. 2001). The Brazilian Amazon covers an area of around 4.3 million $\mathrm{km}^{2}$, about $50 \%$ of the of the country's territory. The region has a population of roughly 21.6 million people, $72 \%$ of whom live in cities in nine Brazilian states (Amazonas, Acre, Rondônia, Roraima, Amapá, Pará, Mato Grosso, Maranhão, and Tocantins) (Silva et al. 2017).

\section{Federal protected areas}

We evaluated 118 federal PAs established before 2010 in the Brazilian Amazon, totaling an area of around $600000 \mathrm{~km}^{2}$ (Fig. 1, Table 1, Table S1). Of these 118 PAs, 38 are strictly protected (Biological Reserve (Rebio), $n=9$, IUCN Ia; Ecological Station (Esec), n = 10, IUCN Ia; and National Park (Parna), $\mathrm{n}=19$, IUCN II), and 80 are sustainable use (Area of Relevant Ecological Interest (Arie), $n=3$, IUCN IV; Environmental Protection Area (Apa), n = 2, IUCN V; National Forest (Flona), $\mathrm{n}=32$, IUCN VI; Sustainable Development Reserve (RDS), $\mathrm{n}=1$, IUCN VI; and Extractive Reserve (Resex), $n=42$, IUCN VI). Although fewer strictly protected than sustainable use reserves were analyzed, these two major classes of PA have similar total areas (strictly protected: roughly $295000 \mathrm{~km}^{2}$ and sustainable use: roughly $305000 \mathrm{~km}^{2}$ ). In total, we studied $91.5 \%$ of the PAs managed by the federal government in Amazonia, which corresponds roughly $76 \%$ of the total territory in federal PAs. Overall, Brazil have $789280 \mathrm{~km}^{2}$ distributed in 326 PAs managed by the federal government across the country and 127 PAs in Amazonia (ICMBio 2016a).

All PAs are forested, with a few also featuring grasslands and savannas. Thirteen PAs are coastal/marine reserves. We excluded nine areas established after 2010, because we analyzed the period of illegal activity spanning from 2010 to 2015. In our study, only PAs (conservation unities) managed by the federal government under the Brazilian System of Conservation Units (SNUC) (Brasil 2000) were evaluated. Therefore, for the purpose of this study, we excluded state, municipal and private areas, as well as indigenous lands and quilombola lands (traditional AfroBrazilian communal territories).

\section{Illegal use of natural resources}

Official figures for illegal use of natural resources (hereafter illegal activities) within federal PAs in the Brazilian Amazon were obtained by analysis of 4243 environmental infraction records (Data S1, Table S1). Irregularities are framed according to Federal Decree 6514 (2008), which deals with administrative environmental infractions and penalties (Brasil 2008). For analytical purposes, we considered that each environmental infraction corresponded to an illegal activity.

Due to the large number of types of infraction and considering that the categories presented by the Brazilian Decree are very broad (e.g., hunting and fishing would fall into the same category), a new categorization of illegal activities was proposed. We considered the infraction framework, the number of occurrences of each type of infraction, and the main characteristics of illegal activities (Fig. 2, Table S2). 
163

164

165

166

167

168

169

170

171

172

173

174

175

176

177

178

179

180

181

182

183

184

185

186

187

188

189

190

191

192

193

\section{4}

195

196

197

198

199

200

201

202

203

\section{Protected area accessibility}

We defined accessibility (or accessible area) of PAs as the intersection between the total area of a PA with the area of a $10 \mathrm{~km}$ buffer adjacent to roads and rivers located within or outside PAs. The definition of accessibility within $10 \mathrm{~km}$ of rivers and roads takes into consideration that most natural resource exploitation in the Amazon is limited by transportation. Preliminary work conducted in Amazonia suggested that $10 \mathrm{~km}$ is the maximum distance local people can travel in order to collect non-timber forest resources and/or hunt (Peres \& Lake 2003; Peres \& Terborgh 1995).

To measure accessibility (Fig. S1, Table S2), we used the following procedures: creation of $10 \mathrm{~km}$ buffers around roads and rivers; union of the files produced when applying $10 \mathrm{~km}$ buffers; intersection of buffers and PAs (accessibility or accessible area); calculation of the accessible area $\left(\mathrm{km}^{2}\right)$; and division of the accessible area by the total area of the PA. All roads mapped by the IBGE at 1:250000 were considered (IBGE/DGC 2015). Selection of the main rivers was carried out according to the criteria adopted by the National Water Agency for the characterization of Brazilian rivers, in which main rivers are drainage sections with an area of contribution greater than $20000 \mathrm{~km}^{2}$.

\section{Population density}

Population density was considered at a distance of $50 \mathrm{~km}$ around the PAs. Population density information was obtained from the "Brazilian statistical grid" (IBGE 2016a; IBGE 2016b) prepared by IBGE based on the Brazilian population census of 2010 (IBGE 2010; IBGE 2011). The "Brazilian statistical grid" contains the amount of the Brazilian population in georeferenced polygons from $1 \mathrm{~km}^{2}$ in rural areas and polygons up to $200 \mathrm{~m}^{2}$ in urban areas. The grid is more refined than the municipal level data, which is generally used in studies that analyze demographic and socioeconomic factors for the Brazilian Amazon. For visualization purposes, we elaborated a population density map of the Amazon biome from the "Brazilian statistical grid" (Fig. S2).

In order to produce the population density variable (Table S2) in the area surrounding the PAs, we first created a $50 \mathrm{~km}$ buffer from the perimeter of each PA; then intersected the $50 \mathrm{~km}$ buffer area of each PA with the "Brazilian statistical grid"; and finally divided the population within the buffer area of $50 \mathrm{~km}$ by its area $\left(\mathrm{km}^{2}\right)$. Areas located outside the Brazilian territory and in marine areas were excluded. When PAs were located very close to the border of the Amazon biome, a $50 \mathrm{~km}$ band was considered beyond the limits of the biome, but within Brazilian territory.

\section{Data analysis}

A summary of all environmental infractions in the period from 2010 to 2015 allowed assessment of the main illegal uses of natural resources (by verifying the illegal activities that generated the infraction notices), as well as the categorization of these illegal uses (Fig. 2). The temporal trend of the illegal use of natural resources for the study period was evaluated using a linear regression. The total number of illegal activities was also summarized for each PA (Table S1), in relation to management categories (strictly protected and sustainable use) (Table 1). For further analysis, the three categories of illegal activities with the highest number of records and their totals summarized for each PA were used. In order to take in to account differences in the area of PAs and to standardize our variables, the total number of infractions and the total number of the three 
204 most common infraction categories were divided by the number of years $(n=6)$ and the area of 205 the PA $\left(\mathrm{km}^{2}\right)$. This procedure was performed considering that the PAs have varied sizes and the measure of law enforcement effort that we adopted was the number of infraction records per year.

207

In order to normalize the data, transformations were applied to the following variables: illegal activities $=\log _{10}\left(\left(\right.\right.$ illegal activities $\left.\left.\times 10^{5}\right)+1\right)$; age $=\log _{10}$ protected area age; accessibility $=$ $\sqrt{ }($ accessibility $)$; and population density $=\log _{10}\left(\right.$ population density $\left.\times 10^{5}\right)$.

We used Spearman correlation analysis to evaluate the independence between our environmental variables (Table S3). Variables with weak correlations $\left(r_{s}<0.50\right)$ were retained for use in subsequent analyses. The differences in the influence of management classes of PAs (sustainable use or strictly protected), age, accessibility, and population density, on illegal activities occurring in PAs, were analyzed using generalized additive models (GAMs, Gaussian distribution family) (Guisan et al. 2002; Heegaard 2002; Wood 2017). GAMs were run separately for each of the three most recorded illegal activities. In order to verify possible differences in the number of illegal activities in stryctly terrestrial PAs $(n=105)$ and coastal/marines $(n=13)$ ones, we used a Mann-Whitney $U$ test. All analyses were performed in the R environment for statistical computing (R Development Core Team 2016).

\section{Results}

\section{Federal protected areas and illegal use of natural resources}

Of the 118 PAs evaluated, 107 had at least one infraction reported between 2010 and 2015; only 11 had no records of illegal activities (Fig. 1, Table S1). Overall, there was a decrease in the number of illegal activities within federal protected areas in the Brazilian Amazon for the study period $\left(R^{2}=0.56, p=0.09\right)$. A total of 4243 occurrences of illegal use of natural resources were evaluated, and these resulted in total fines of US\$224646139.84 (Table 1). Strictly protected PAs had a relatively higher total fines value (US\$ 143948856.38) compared to that of sustainable use reserves (US\$ 80697283.46). Similarly, strictly protected PAs presented slightly higher numbers of illegal activities $(n=2179)$ than sustainable use reserves $(n=2064)$. The mean number of total illegal activities in each PA was 35 (median 19.50), with 50\% of PAs within the range of 8.0 to 47.5. The ten PAs with the highest frequency of illegal activities were Rebio do Abufari ( $\mathrm{n}=$ 316), Parna Serra do Divisor $(n=199)$, Parna Mapinguari $(n=187)$, Rebio do Jaru $(n=158)$, Rebio do Gurupi $(n=137)$, Resex Marinha de Soure $(n=129)$, Parna do Cabo Orange $(n=122)$, Rebio Trombetas $(n=122)$, Flona do Jamaxim $(n=97)$, and Resex Chico Mendes $(n=93)$.

We found 27 types of illegal uses of natural resources that were grouped into 10 categories of illegal activities (Fig. 2, Table S2). The most commonly registered infractions were related to suppression and degradation of vegetation (37.36\%), followed by illegal fishing $(27.34 \%)$ and hunting activities $(18.15 \%)$. These three categories together corresponded to $82.85 \%$ of all records of illegal activities in the entire study period. Infractions related to the suppression and degradation of vegetation were responsible for the highest total amount of fines among the 10 categories of illegal activities, US\$ 188337814.39 , which corresponds to around $83 \%$ of all fines imposed in the study period. The four PAs with the highest number of illegal activities related to the suppression and degradation of vegetation were the Parna Serra do Divisor $(n=109)$, Rebio do Gurupi $(n=94)$, Parna Mapinguari $(n=92)$, and Resex Chico Mendes $(n=71)$. For illegal fishing, the Rebio do Abufari $(\mathrm{n}=168)$, the Parna do Cabo Orange $(\mathrm{n}=120)$, the Rebio Jaru $(\mathrm{n}=$ 
246

247

248

249

250

251

252

253

254

255

256

257

258

259

260

261

262

263

264

265

266

267

268

269

270

271

272

273

274

275

\section{6}

277

278

279

280

281

282

283

284

285

286
89), and the Esec Maracá ( $\mathrm{n}=52)$, had the highest number of infractions. Regarding hunting, the four reserves with the majority of records were the Rebio do Abufari $(n=168)$, the Parna Serra do Divisor $(n=72)$, the Rebio Trombetas $(n=46)$, and the Flona Tefé $(n=35)$.

\section{Predictors of illegal activities within Federal protected areas}

The mean age of federal PAs in the Brazilian Amazon (calculated from 2015) was 18.92 years (median $=14$, range $=6-54$ years), with $50 \%$ of reserves ranging in age from 10 to 26 years. The total mean area of the PAs was $5092.66 \mathrm{~km}^{2}\left(\right.$ median $\left.=2858.73 \mathrm{~km}^{2}\right)$. The reserves ranging from 1209.90 to $6813.01 \mathrm{~km}^{2}$ in a $50 \mathrm{~km}$ buffer population density around PAs averaged 7.49 inhabitants per $\mathrm{km}^{2}$ (median $=1.54$ inhabitants $/ \mathrm{km}^{2}$ ), with $50 \%$ of the PAs ranging from 0.63 to 4.68 inhabitants per $\mathrm{km}^{2}$. The protected area with the lowest population density in the surroundings was the Resex do Xingu with 0.06 inhabitants $/ \mathrm{km}^{2}$ and the highest density was found in the neighborhood of Parna Anavilhanas with 75.90 inhabitants $/ \mathrm{km}^{2}$. The overall index of accessibility was on average $43 \%$ (median $=33 \%$ ), and $50 \%$ of PAs had accessibility between $15 \%$ and $68 \%$. Regarding accessibility, it is important to highlight that 17 PAs presented 100\% of this variable, as well as 10 PAs had zero accessibility (Table S1).

The explanatory power of the GAMs was low for all groups (Table 2), with a maximum explained variation of $41.20 \%\left(\mathrm{R}^{2}\right.$ adjusted $\left.=0.39\right)$ for total illegal activities, and a minimum of $14.6 \%\left(\mathrm{R}^{2}\right.$ adjusted 0.12 ) for illegal hunting activities. From all explanatory variables analyzed in our study, population density was the most important predictor of total number of infractions (Fig. 3), as well as illegal fishing, suppression and degradation of vegetation, and hunting. The second most important predictor of illegal activities was accessibility, which was positively related to all illegal activities (Fig. 4) and to illegal fishing. PA classification was only an important predictor for illegal fishing, with sustainable use PAs having lower levels of illegal fishing. The age of a PA was not a significant predictor for any of the illegal activities analyzed in our study.

In relation to the number of illegal activities and the PA location (coastal/marine or terrestrial), we found a significant decrease in the number of all illegal activities $(p<0.001)$ and a significant increase in the number of illegal fishing $(\mathrm{p}<0.001)$ in coastal/marine PAs (Table S4). Illegal activities related with hunting and flora degradation were not significantly different in these two locations of PAs.

\section{Discussion}

Globally, the illegal use of natural resources is one of the biggest threats to biodiversity, and generally threatens the integrity of PAs and the viability of endangered species (Conteh et al. 2015; Dinerstein et al. 2007; Gavin et al. 2010; Laurance et al. 2012). Despite the fact that Amazonian PAs are one of the most important means of reducing deforestation rates in the biome (Kere et al. 2017), PA creation alone is not sufficient to reduce threats to biological diversity.

Our analysis showed that there was a wide range of illegal activities that threatens the biodiversity of Amazonian federal PAs. We found that illegal activities related to suppression and degradation of vegetation, illegal fishing and hunting activities were the most commonly recorded. These three activities have been highlighted in several assessments of biodiversity threats globally: hunting and the illegal wildlife trade (Dudley et al. 2013; Nijman 2015; Sharma 
287 et al. 2014; Tella \& Hiraldo 2014; Underwood et al. 2013); fishing in prohibited locations, 288 outside permitted periods and in excess of established quantities or sizes (Free et al. 2015; Sethi 289 \& Hilborn 2008; Thomas et al. 2015); and illegal logging, deforestation and degradation of 290 vegetation (Chicas et al. 2017; Curran et al. 2004; Funi \& Paese 2012; Yonariza \& Webb 2007). 291 Although illegal activities related to the suppression and degradation of vegetation, illegal 292 fishing, and poaching activities were those most frequently recorded in Amazonian PAs, it does 293 not mean that other less prominent illegal activities are not of concern.

294 The population density surrounding PAs was the most important variable in our study, predicting 295 total illegal activities, as well as the suppression and degradation of vegetation, illegal fishing, 296 and poaching activities. This finding is in line with the results of other tropical forest studies that 297 have observed a positive relationship between the growth of human populations and an increase 298 in natural resource extraction and deforestation (Geist \& Lambin 2002; Laurance et al. 2014; 299 Lewis et al. 2015; Lopez-Carr \& Burgdorfer 2013; Marques et al. 2016).

300 We found that accessibility was positively related only with the total number of illegal activities 301 and to illegal fishing, while for hunting activities and vegetation suppression and degradation 302 activities this variable was marginally significant. Despite this, it was possible to verify the 303 importance of accessibility in predicting illegal activities within PAs. Roads and highways have a 304 fundamental role in opening the tropics to destructive colonization and exploitation (Laurance et 305 al. 2001). Roads provide access and dispersion of people within tropical forests and facilitate access for hunters, miners, land speculators, and others into forest core areas (Laurance et al. 2009). For example, the increasing deforestation of the Brazilian Amazon began with the construction of the Belém-Brasília highway in the 1960s (Vieira et al. 2008) and the opening of the Transamazon Highway in 1970 (Fearnside 2005). Barber et al. (2014) observed that until 2006, deforestation in the Brazilian Amazon was higher in areas closer to roads and rivers, with almost $95 \%$ of the total deforested area within $5.5 \mathrm{~km}$ of roads and up to $1 \mathrm{~km}$ from rivers. Recent studies show that populations of aquatic species (e.g., giant otters, alligators) in more accessible areas have collapsed throughout the Amazon basin (Antunes et al. 2016).

We found no relationship between the age of PAs and illegal activities, although the age of a PA is often correlated with conservation results (Claudet et al. 2008; Molloy et al. 2009; Soares-Filho et al. 2010). Our results show that sustainable use PAs decrease the frequency of illegal fishing activities. This relationship can be attributed to the fact that residents of the reserves assist surveillance. Nepstad et al. (2006) verified that sustainable use PAs and indigenous lands hold great importance for the prevention of deforestation and wildfires. This pattern was also observed in a global analysis of the effectiveness of strictly protected and sustainable use PAs in reducing tropical forest fires, where sustainable use PAs were more efficient (Nelson \& Chomitz 2011). Porter-Bolland et al. (2012) observed that forests managed by communities presented lower and less variable deforestation rates across the tropics. These findings reinforce the idea that in order to achieve an effective conservation, it is necessary to involve local communities in environmental governance (Brondizio \& Le Tourneau 2016; Dudley et al. 2014).

Despite differences found in the decrease in the number of total illegal activities and the increase in illegal fishing activities in coastal/marine when compared with terrestrial PAs, we did not find significant differences for illegal activities of hunting and flora degradation. Overall, a greater number of fisheries-related offenses are expected in coastal marine areas. However, coastal 
330

331

332

333

334

335

336

337

338

339

340

341

342

343

344

345

346

347

348

349

350

351

352

353

354

355

356

357

358

359

360

361

362

363

364

365

366

367

368

369

370

371

marine PAs that occur in the Brazilian Amazon have also significant portions of forests (mainly mangrove formations). Thus, it is not surprising that illegal hunting and flora degradation were present in these areas in similar levels of terrestrial PAs. On the other hand, the differences presented here indicate the need for a more detailed evaluation of these different locations of PAs, which could be coupled with differences in strategies and conservation actions to be applied to individual areas (Barber et al. 2012; Margules \& Pressey 2000).

\section{Conclusions}

PAs are fundamental for biodiversity conservation across the Brazilian Amazon, and their establishment and maintenance is a key strategy for protection from the pressures and threats posed by human presence in tropical forests. Nonetheless, PAs are one of the most crucial factors contributing to reductions in deforestation in this biome. We report several threats that may impair long-term conservation and many efforts are still needed to address these issues. The use of enforcement reports generated by official government authorities provides us with a more nuanced view of the illegal activities taking place within PAs in the Brazilian Amazon. We demonstrated that this type of information can be useful as a complement to more sophisticated remote sensing techniques that usually fail to identify threats under the forest canopy. We have showed that the monitoring information helps to identify more problematic PAs in relation to the illegal use of natural resources and in relation to detailed categories of infraction. This can help managers to plan and implement specific conservation actions to individual areas in order to reduce illegal activities. Additionally, information regarding enforcement effort applied in each PA can be better quantified, which would help conservationists and practioners to be able to evaluate and set goals for different PAs under different regimes and locations. Implement management actions in and around PAs are key conservation issues that will need to be addressed to provide the realization of effectiveness goals of de facto preservation of the Brazilian Amazon.

\section{Acknowledgements}

We wish to thank DMIF/CGPRO/ICMBio for providing access to illegal activities (fines) recorded within the Federal Protected Areas, in special for the ICMBio environmental analysts Kelly Borges, Mariella Butti, and Andre Alamino. We would like to thank Luis Barbosa for assistance with some GIS procedures.

\section{References}

Alves DS. 2002. Space-time dynamics of deforestation in Brazilian Amazônia. International Journal of Remote Sensing 23:2903-2908. 10.1080/01431160110096791

ANA. 2013. Base hidrográfica ottocodificada multiescalas 2013. Available at http://metadados.ana.gov.br/geonetwork/srv/pt/main.home (accessed 08/03 2017).

Antunes AP, Fewster RM, Venticinque EM, Peres CA, Levi T, Rohe F, and Shepard GH, Jr. 2016. Empty forest or empty rivers? A century of commercial hunting in Amazonia. Sci Adv 2:e1600936. 10.1126/sciadv.1600936

Barber CP, Cochrane MA, Souza C, and Veríssimo A. 2012. Dynamic performance assessment of protected areas. Biological Conservation 149:6-14. 10.1016/j.biocon.2011.08.024

Barber CP, Cochrane MA, Souza CM, and Laurance WF. 2014. Roads, deforestation, and the mitigating effect of protected areas in the Amazon. Biological Conservation 177:203-209. 10.1016/j.biocon.2014.07.004 
372

373

374

375

376

377

378

379

380

381

382

383

384

385

386

387

388

389

390

391

392

393

394

395

396

397

398

399

400

401

402

403

404

405

406

407

408

409

410

411

412

413

414

415

416

417

418

419

Brasil. 2000. Lei No 9985, de 18 de Julho de 2000 - Institui o Sistema Nacional de Unidades de Conservação da Natureza - SNUC.: Diário Oficial da União.

Brasil. 2008. Decreto $N^{\circ}$ 6.514, de 22 de Julho de 2008 - Dispõe sobre as infrações e sanções administrativas ao meio ambiente.: Diário Oficial da União.

Brondizio ES, and Le Tourneau FM. 2016. ENVIRONMENT. Environmental governance for all. Science 352:1272-1273. 10.1126/science.aaf5122

Chicas SD, Omine K, Ford JB, Sugimura K, and Yoshida K. 2017. Using spatial metrics and surveys for the assessment of trans-boundary deforestation in protected areas of the Maya Mountain Massif: Belize-Guatemala border. Journal of Environmental Management 187:320-329. 10.1016/j.jenvman.2016.11.063

Claudet J, Osenberg CW, Benedetti-Cecchi L, Domenici P, Garcia-Charton JA, Perez-Ruzafa A, Badalamenti F, Bayle-Sempere J, Brito A, Bulleri F, Culioli JM, Dimech M, Falcon JM, Guala I, Milazzo M, Sanchez-Meca J, Somerfield PJ, Stobart B, Vandeperre F, Valle C, and Planes S. 2008. Marine reserves: size and age do matter. Ecology Letters 11:481-489. 10.1111/j.1461-0248.2008.01166.x

Conteh A, Gavin MC, and Solomon J. 2015. Quantifying illegal hunting: A novel application of the quantitative randomised response technique. Biological Conservation 189:16-23. 10.1016/j.biocon.2015.02.002

Curran LM, Trigg SN, McDonald AK, Astiani D, Hardiono YM, Siregar P, Caniago I, and Kasischke E. 2004. Lowland forest loss in protected areas of Indonesian Borneo. Science 303:1000-1003. 10.1126/science.1091714

Dalla-Nora EL, de Aguiar APD, Lapola DM, and Woltjer G. 2014. Why have land use change models for the Amazon failed to capture the amount of deforestation over the last decade? Land Use Policy 39:403-411. 10.1016/j.landusepol.2014.02.004

de Toledo PM, Dalla-Nora E, Vieira ICG, Aguiar APD, and Araújo R. 2017. Development paradigms contributing to the transformation of the Brazilian Amazon: do people matter? Current Opinion in Environmental Sustainability 26-27:77-83.

10.1016/j.cosust.2017.01.009

Dinerstein E, Loucks C, Wikramanayake E, Ginsberg J, Sanderson E, Seidensticker J, Forrest J, Bryja G, Heydlauff A, Klenzendorf S, Leimgruber P, Mills J, O'Brien TG, Shrestha M, Simons R, and Songer M. 2007. The Fate of Wild Tigers. Bioscience 57:508. $10.1641 / \mathrm{b} 570608$

Dudley N. 2008. Guidelines for applying protected area management categories. Gland, Switzerland: IUCN.

Dudley N, Groves C, Redford KH, and Stolton S. 2014. Where now for protected areas? Setting the stage for the 2014 World Parks Congress. Oryx 48:496-503. $10.1017 / \mathrm{s} 0030605314000519$

Dudley N, Stolton S, and Elliott W. 2013. Editorial: Wildlife crime poses unique challenges to protected areas. Parks 19:7-12. 10.2305/IUCN.CH.2013.PARKS-19-1.ND.en

Fearnside PM. 2005. Deforestation in Brazilian Amazonia: History, Rates, and Consequences. Conservation Biology 19:680-688. 10.1111/j.1523-1739.2005.00697.x

Free CM, Jensen OP, and Mendsaikhan B. 2015. A Mixed-Method Approach for Quantifying Illegal Fishing and Its Impact on an Endangered Fish Species. PLoS One 10:e0143960. 10.1371/journal.pone.0143960

Funi C, and Paese A. 2012. Spatial and temporal patterns of deforestation in Rio Cajari Extrative Reserve, Amapa, Brazil. PLoS One 7:e51893. 10.1371/journal.pone.0051893

Gavin MC, Solomon JN, and Blank SG. 2010. Measuring and monitoring illegal use of natural resources. Conservation Biology 24:89-100. 10.1111/j.1523-1739.2009.01387.x 
420

421

422

423

424

425

426

427

428

429

430

431

432

433

434

435

436

437

438

439

440

441

442

443

444

445

446

447

448

449

450

451

452

453

454

455

456

457

458

459

460

461

462

463

464

465

466

467

468

Geist HJ, and Lambin EF. 2002. Proximate Causes and Underlying Driving Forces of Tropical Deforestation. Bioscience 52:143. 10.1641/0006-3568(2002)052[0143:pcaudf]2.0.co;2

Góes Filho L, and Veloso HP. 1982. Fitogeografia brasileira : classificação fisionômico ecológica da vegetação neotropical. In: RADAMBRASIL IP, editor. Projeto RADAMBRASIL. Salvador: Ministério de Minas e Energia. p 86.

Guisan A, Edwards TC, and Hastie T. 2002. Generalized linear and generalized additive models in studies of species distributions: setting the scene. Ecological Modelling 157:89-100. 10.1016/s0304-3800(02)00204-1

Heegaard E. 2002. The outer border and central border for species-environmental relationships estimated by non-parametric generalised additive models. Ecological Modelling 157:131139. 10.1016/s0304-3800(02)00191-6

IBGE. 2004. Mapa de Biomas do Brasil. Available at ftp://geoftp.ibge.gov.br/informacoes ambientais/vegetacao/mapas/brasil/biomas.pdf.

IBGE. 2010. Censo demográfico 2010. Available at http://censo2010.ibge.gov.br/ (accessed 03/02 2017).

IBGE. 2011. Sinopse do censo demográficco 2010. Rio de Janeiro: Instituto Brasileiro de Geograf a e Estatística - IBGE.

IBGE. 2016a. Grade estatística. Available at ftp://geoftp.ibge.gov.br/recortes_para fins_estatisticos/grade estatistica/censo_2010/ (accessed 03/08 2017).

IBGE. 2016b. Grade Estatística. Rio de Janeiro: Instituto Brasileiro de Geografia e Estatística. p 28.

IBGE/DGC. 2015. Base Cartográfica Contínua do Brasil, 1:250000 - BC250: versão 2015. Available at ftp://geoftp.ibge.gov.br/cartas_e mapas/bases_cartograficas_continuas/bc250/versao2015/ (accessed 03/08 2017).

ICMBio. 2016a. Resumo de UCs Federais por Bioma. Available at http://www.icmbio.gov.br/portal/images/stories/servicos/geoprocessamento/DCOL/dados tabulares/UC_bioma_resumo_agosto_2016.pdf (accessed 09/20 2016).

ICMBio. 2016b. Shapefile Limites das Unidades de Conservação Federais. Available at http://www.icmbio.gov.br/portal/geoprocessamento1 (accessed 09/20 2016).

ICMBio/DMIF. 2017. Autos de infração nas Unidades de Conservação Federais da Amazônia Brasileira. Available at Instituto Chico Mendes de Conservação da Biodiversidade/Coordenação Geral de Proteção/Divisão de Monitoramento e Informação Ambiental (accessed 02/01 2017).

Jusys T. 2016. Fundamental causes and spatial heterogeneity of deforestation in Legal Amazon. Applied Geography 75:188-199. 10.1016/j.apgeog.2016.08.015

Kere EN, Choumert J, Combes Motel P, Combes JL, Santoni O, and Schwartz S. 2017. Addressing Contextual and Location Biases in the Assessment of Protected Areas Effectiveness on Deforestation in the Brazilian Amazônia. Ecological Economics 136:148-158. 10.1016/j.ecolecon.2017.02.018

Laurance WF, Albernaz AKM, Schroth G, Fearnside PM, Bergen S, Venticinque EM, and Da Costa C. 2002. Predictors of deforestation in the Brazilian Amazon. Journal of Biogeography 29:737-748. 10.1046/j.1365-2699.2002.00721.x

Laurance WF, Cochrane MA, Bergen S, Fearnside PM, Delamonica P, Barber C, D'Angelo S, and Fernandes T. 2001. The future of the Brazilian Amazon. Science 291:438-439. 10.1126/science.291.5503.438

Laurance WF, Goosem M, and Laurance SG. 2009. Impacts of roads and linear clearings on tropical forests. Trends in Ecology \& Evolution 24:659-669. 10.1016/j.tree.2009.06.009 
469

470

471

472

473

474

475

476

477

478

479

480

481

482

483

484

485

486

487

488

489

490

491

492

493

494

495

496

497

498

499

500

501

502

503

504

505

506

507

508

509

510

511

512

513

514

515
Laurance WF, Sayer J, and Cassman KG. 2014. Agricultural expansion and its impacts on tropical nature. Trends in Ecology \& Evolution 29:107-116. 10.1016/j.tree.2013.12.001

Laurance WF, Useche DC, Rendeiro J, Kalka M, Bradshaw CJ, Sloan SP, Laurance SG, Campbell M, Abernethy K, Alvarez P, Arroyo-Rodriguez V, Ashton P, Benitez-Malvido J, Blom A, Bobo KS, Cannon CH, Cao M, Carroll R, Chapman C, Coates R, Cords M, Danielsen F, De Dijn B, Dinerstein E, Donnelly MA, Edwards D, Edwards F, Farwig N, Fashing P, Forget PM, Foster M, Gale G, Harris D, Harrison R, Hart J, Karpanty S, Kress WJ, Krishnaswamy J, Logsdon W, Lovett J, Magnusson W, Maisels F, Marshall AR, McClearn D, Mudappa D, Nielsen MR, Pearson R, Pitman N, van der Ploeg J, Plumptre A, Poulsen J, Quesada M, Rainey H, Robinson D, Roetgers C, Rovero F, Scatena F, Schulze C, Sheil D, Struhsaker T, Terborgh J, Thomas D, Timm R, Urbina-Cardona JN, Vasudevan K, Wright SJ, Arias GJ, Arroyo L, Ashton M, Auzel P, Babaasa D, Babweteera F, Baker P, Banki O, Bass M, Bila-Isia I, Blake S, Brockelman W, Brokaw N, Bruhl CA, Bunyavejchewin S, Chao JT, Chave J, Chellam R, Clark CJ, Clavijo J, Congdon R, Corlett R, Dattaraja HS, Dave C, Davies G, Beisiegel Bde M, da Silva Rde N, Di Fiore A, Diesmos A, Dirzo R, Doran-Sheehy D, Eaton M, Emmons L, Estrada A, Ewango C, Fedigan L, Feer F, Fruth B, Willis JG, Goodale U, Goodman S, Guix JC, Guthiga P, Haber W, Hamer K, Herbinger I, Hill J, Huang Z, Sun IF, Ickes K, Itoh A, Ivanauskas N, Jackes B, Janovec J, Janzen D, Jiangming M, Jin C, Jones T, Justiniano H, Kalko E, Kasangaki A, Killeen T, King HB, Klop E, Knott C, Kone I, Kudavidanage E, Ribeiro JL, Lattke J, Laval R, Lawton R, Leal M, Leighton M, Lentino M, Leonel C, Lindsell J, LingLing L, Linsenmair KE, Losos E, Lugo A, Lwanga J, Mack AL, Martins M, McGraw WS, McNab R, Montag L, Thompson JM, Nabe-Nielsen J, Nakagawa M, Nepal S, Norconk M, Novotny V, O'Donnell S, Opiang M, Ouboter P, Parker K, Parthasarathy N, Pisciotta K, Prawiradilaga D, Pringle C, Rajathurai S, Reichard U, Reinartz G, Renton K, Reynolds G, Reynolds V, Riley E, Rodel MO, Rothman J, Round P, Sakai S, Sanaiotti T, Savini T, Schaab G, Seidensticker J, Siaka A, Silman MR, Smith TB, de Almeida SS, Sodhi N, Stanford C, Stewart K, Stokes E, Stoner KE, Sukumar R, Surbeck M, Tobler M, Tscharntke T, Turkalo A, Umapathy G, van Weerd M, Rivera JV, Venkataraman M, Venn L, Verea C, de Castilho CV, Waltert M, Wang B, Watts D, Weber W, West P, Whitacre D, Whitney K, Wilkie D, Williams S, Wright DD, Wright P, Xiankai L, Yonzon P, and Zamzani F. 2012. Averting biodiversity collapse in tropical forest protected areas. Nature 489:290-294. 10.1038/nature11318

Lewis SL, Edwards DP, and Galbraith D. 2015. Increasing human dominance of tropical forests. Science 349:827-832. 10.1126/science.aaa9932

Lopez-Carr D, and Burgdorfer J. 2013. Deforestation Drivers: Population, Migration, and Tropical Land Use. Environment 55. 10.1080/00139157.2013.748385

Lopez-Carr D, Lopez AC, and Bilsborrow RE. 2009. The population, agriculture, and environment nexus in Latin America: country-level evidence from the latter half of the twentieth century. Population and Environment 30:222-246. 10.1007/s11111-009-0090-4

Margules CR, and Pressey RL. 2000. Systematic conservation planning. Nature 405:243-253. $10.1038 / 35012251$

Marques AAd, Schneider M, and Peres CA. 2016. Human population and socioeconomic modulators of conservation performance in 788 Amazonian and Atlantic Forest reserves. PeerJ 4:e2206. 10.7717/peerj.2206

MMA. 2016. Shapefile dos biomas do Brasil. Available at http://mapas.mma.gov.br/i3geo/datadownload.htm\# (accessed 09/20 2016). 
516

517

518

519

520

521

522

523

524

525

526

527

528

529

530

531

532

533

534

535

536

537

538

539

540

541

542

543

544

545

546

547

548

549

550

551

552

553

554

555

556

557

558

559

560

561

562

563

Molloy PP, McLean IB, and Côté IM. 2009. Effects of marine reserve age on fish populations: a global meta-analysis. Journal of Applied Ecology 46:743-751. 10.1111/j.13652664.2009.01662.x

Nelson A, and Chomitz KM. 2011. Effectiveness of strict vs. multiple use protected areas in reducing tropical forest fires: a global analysis using matching methods. PLoS One 6:e22722. 10.1371/journal.pone.0022722

Nepstad D, McGrath D, Stickler C, Alencar A, Azevedo A, Swette B, Bezerra T, DiGiano M, Shimada J, Seroa da Motta R, Armijo E, Castello L, Brando P, Hansen MC, McGrathHorn M, Carvalho O, and Hess L. 2014. Slowing Amazon deforestation through public policy and interventions in beef and soy supply chains. Science 344:1118-1123. 10.1126/science. 1248525

Nepstad D, Schwartzman S, Bamberger B, Santilli M, Ray D, Schlesinger P, Lefebvre P, Alencar A, Prinz E, Fiske G, and Rolla A. 2006. Inhibition of Amazon Deforestation and Fire by Parks and Indigenous Lands. Conservation Biology 20:65-73. 10.1111/j.15231739.2006.00351.x

Nepstad D, Soares-Filho BS, Merry F, Lima A, Moutinho P, Carter J, Bowman M, Cattaneo A, Rodrigues H, Schwartzman S, McGrath DG, Stickler CM, Lubowski R, Piris-Cabezas P, Rivero S, Alencar A, Almeida O, and Stella O. 2009. Environment. The end of deforestation in the Brazilian Amazon. Science 326:1350-1351. 10.1126/science.1182108 Nijman. 2015. PANGOLIN SEIZURES DATA REPORTED. TRAFFIC Bulletin 27:44-46. Olson DM, Dinerstein E, Wikramanayake ED, Burgess ND, Powell GVN, Underwood EC, D'Amico JA, Itoua I, Strand HE, Morrison JC, Loucks CJ, Allnutt TF, Ricketts TH, Kura Y, Lamoreux JF, Wettengel WW, Hedao P, and Kassem KR. 2001. Terrestrial Ecoregions of the World: A New Map of Life on Earth. Bioscience 51:933. 10.1641/00063568(2001)051[0933:teotwa]2.0.co;2

Peres CA, Barlow J, and Laurance WF. 2006. Detecting anthropogenic disturbance in tropical forests. Trends in Ecology \& Evolution 21:227-229. 10.1016/j.tree.2006.03.007

Peres CA, and Lake IR. 2003. Extent of Nontimber Resource Extraction in Tropical Forests: Accessibility to Game Vertebrates by Hunters in the Amazon Basin. Conservation Biology 17:521-535. 10.1046/j.1523-1739.2003.01413.x

Peres CA, and Terborgh JW. 1995. Amazonian Nature Reserves: An Analysis of the Defensibility Status of Existing Conservation Units and Design Criteria for the Future. Conservation Biology 9:34-46. 10.1046/j.1523-1739.1995.09010034.x

Pfaff A, Robalino J, Herrera D, and Sandoval C. 2015. Protected Areas' Impacts on Brazilian Amazon Deforestation: Examining Conservation-Development Interactions to Inform Planning. PLoS One 10:e0129460. 10.1371/journal.pone.0129460

Porter-Bolland L, Ellis EA, Guariguata MR, Ruiz-Mallén I, Negrete-Yankelevich S, and ReyesGarcía V. 2012. Community managed forests and forest protected areas: An assessment of their conservation effectiveness across the tropics. Forest Ecology and Management 268:6-17. 10.1016/j.foreco.2011.05.034

R DCT. 2016. R: A Language and Environment for Statistical Computing. 3.2.5 ed. Vienna, Austria: R Foundation for Statistical Computing.

Schwartzman S, Alencar A, Zarin H, and Santos Souza AP. 2010. Social Movements and LargeScale Tropical Forest Protection on the Amazon Frontier: Conservation From Chaos. The Journal of Environment \& Development. 10.1177/1070496510367627

Sethi SA, and Hilborn R. 2008. Interactions between poaching and management policy affect marine reserves as conservation tools. Biological Conservation 141:506-516. 10.1016/j.biocon.2007.11.005 
564

565

566

567

568

569

570

571

572

573

574

575

576

577

578

579

580

581

582

583

584

585

586

587

588

589

590

591

592

593

594

595

596

597

598
Sharma K, Wright B, Joseph T, and Desai N. 2014. Tiger poaching and trafficking in India: Estimating rates of occurrence and detection over four decades. Biological Conservation 179:33-39. 10.1016/j.biocon.2014.08.016

Silva JMCd, Prasad S, and Diniz-Filho JAF. 2017. The impact of deforestation, urbanization, public investments, and agriculture on human welfare in the Brazilian Amazonia. Land Use Policy 65:135-142. 10.1016/j.landusepol.2017.04.003

Silva JMCd, Rylands AB, and Da Fonseca GAB. 2005. The fate of the Amazonian areas of endemism. Conservation Biology 19:689-694. 10.1111/j.1523-1739.2005.00705.x

Soares-Filho B, Moutinho P, Nepstad D, Anderson A, Rodrigues H, Garcia R, Dietzsch L, Merry F, Bowman M, Hissa L, Silvestrini R, and Maretti C. 2010. Role of Brazilian Amazon protected areas in climate change mitigation. Proc Natl Acad Sci U S A 107:10821-10826. 10.1073/pnas.0913048107

Soares-Filho BS, Nepstad DC, Curran LM, Cerqueira GC, Garcia RA, Ramos CA, Voll E, McDonald A, Lefebvre P, and Schlesinger P. 2006. Modelling conservation in the Amazon basin. Nature 440:520-523. 10.1038/nature04389

Tella JL, and Hiraldo F. 2014. Illegal and legal parrot trade shows a long-term, cross-cultural preference for the most attractive species increasing their risk of extinction. PLoS One 9:e107546. 10.1371/journal.pone.0107546

Thomas AS, Gavin MC, and Milfont TL. 2015. Estimating non-compliance among recreational fishers: Insights into factors affecting the usefulness of the randomized response and item count techniques. Biological Conservation 189:24-32. 10.1016/j.biocon.2014.09.048

Tritsch I, and Le Tourneau F-M. 2016. Population densities and deforestation in the Brazilian Amazon: New insights on the current human settlement patterns. Applied Geography 76:163-172. 10.1016/j.apgeog.2016.09.022

Underwood FM, Burn RW, and Milliken T. 2013. Dissecting the illegal ivory trade: an analysis of ivory seizures data. PLoS One 8:e76539. 10.1371/journal.pone.0076539

Vieira ICG, Toledo PM, Silva JMC, and Higuchi H. 2008. Deforestation and threats to the biodiversity of Amazonia. Brazilian Journal of Biology 68:949-956. 10.1590/s151969842008000500004

Wood SN. 2017. mgcv: Mixed GAM Computation Vehicle with GCV/AIC/REML Smoothness Estimation. R package version 1.8-17. Available at https://CRAN.Rproject.org/package $=$ mgcv (accessed 04/19 2017).

Yonariza, and Webb EL. 2007. Rural household participation in illegal timber felling in a protected area of West Sumatra, Indonesia. Environmental Conservation 34:73. $10.1017 / \mathrm{s} 0376892907003542$ 


\section{Figure 1}

Illegal activities in the Brazilian Amazon federal protected areas.

Brazilian Amazon federal protected areas (Sustainable use and Strictly protected), and 4243 occurrences (grouped per PA) of illegal use of natural resources (illegal activities) in the period of 2010-2015.

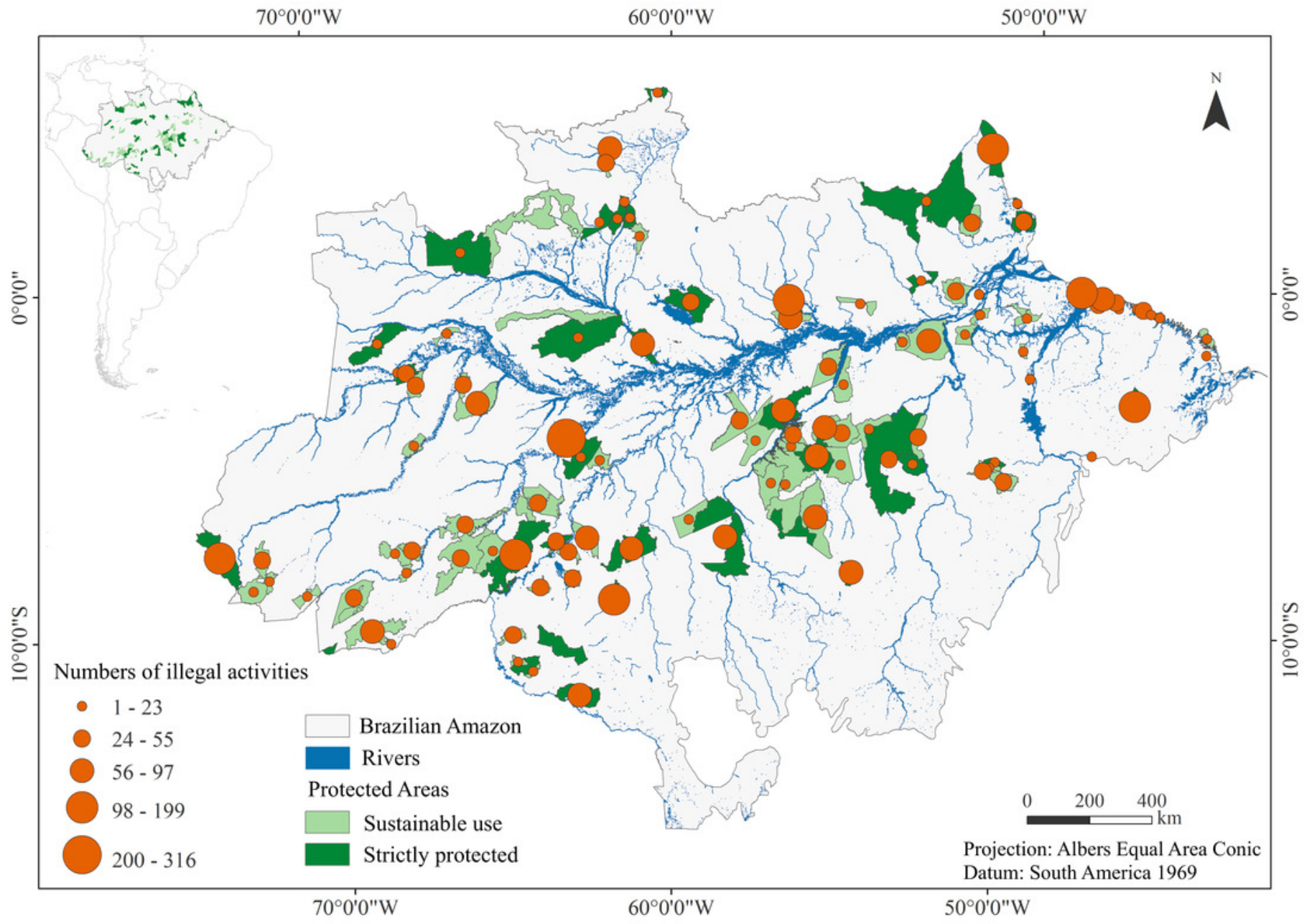




\section{Figure 2}

Illegal activities category and total number of occurrence.

Official figures for illegal use of natural resources (illegal activities) within federal PAs in the Brazilian Amazon obtained by analysis of 4243 environmental infraction records.

Categorization of illegal activities considered the infraction framework, the number of occurrences of each type of infraction (according to the Brazilian Federal Decree 6514 (2008)), and the main characteristics of illegal activities.

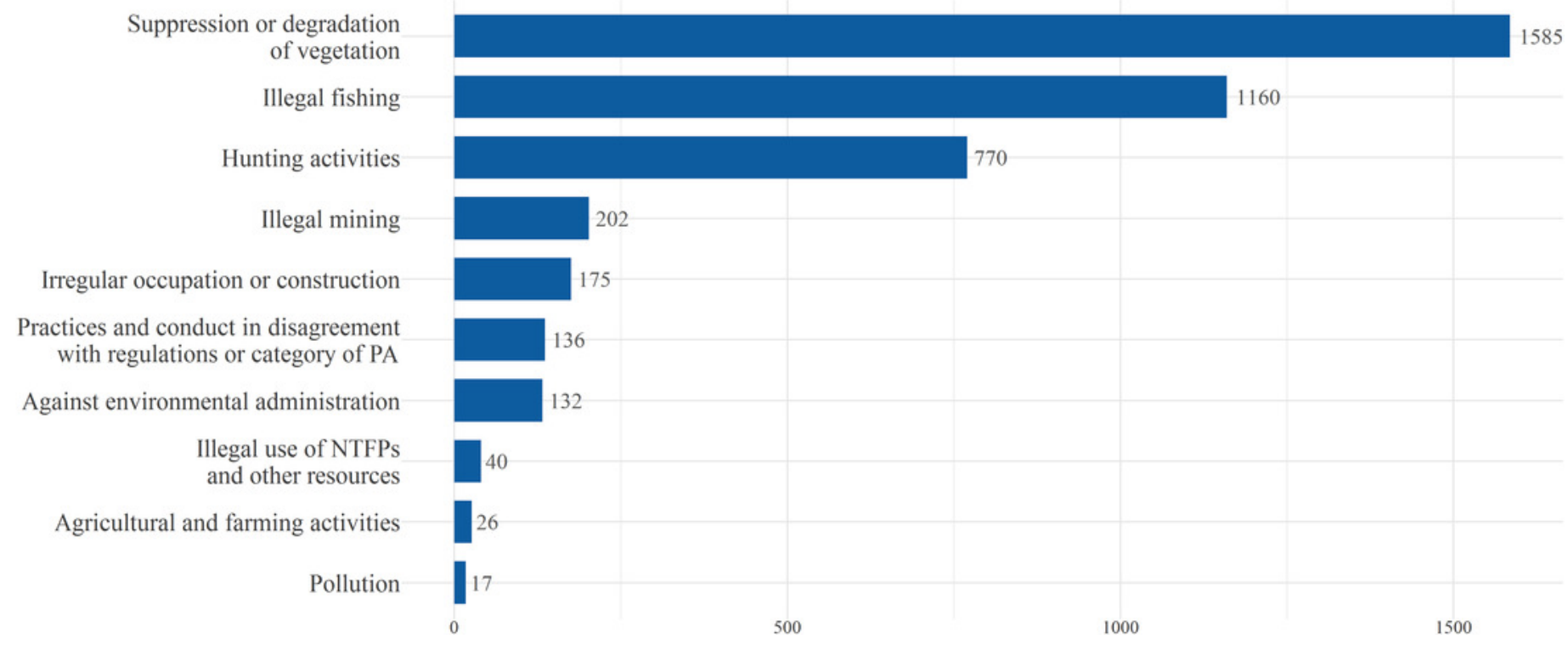


Figure 3

Total of all illegal activities and human population density in a $50 \mathrm{~km}$ buffer from the perimeter of each protected area.

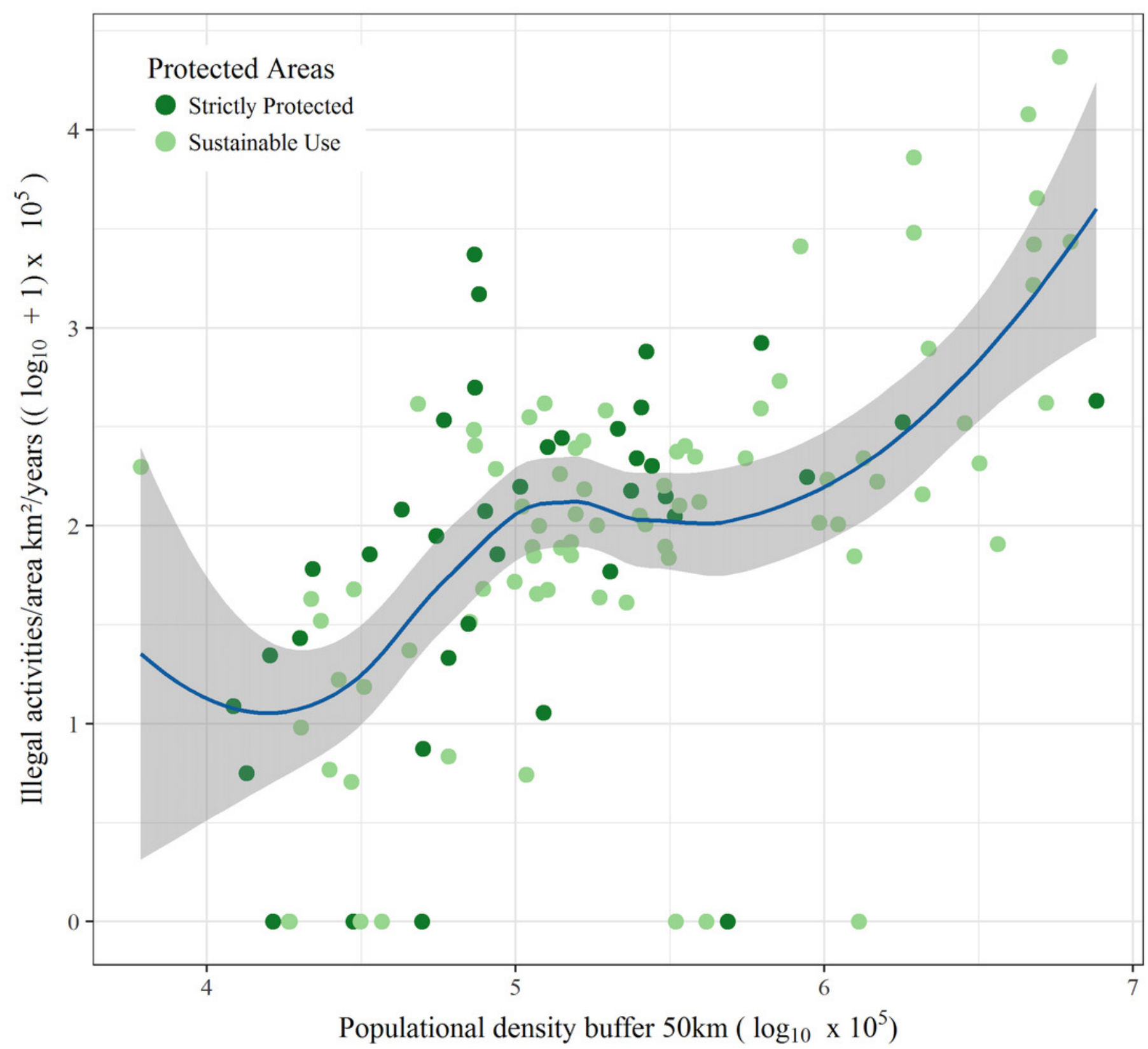


Figure 4

Total of all illegal activities and accessibility of protected areas.

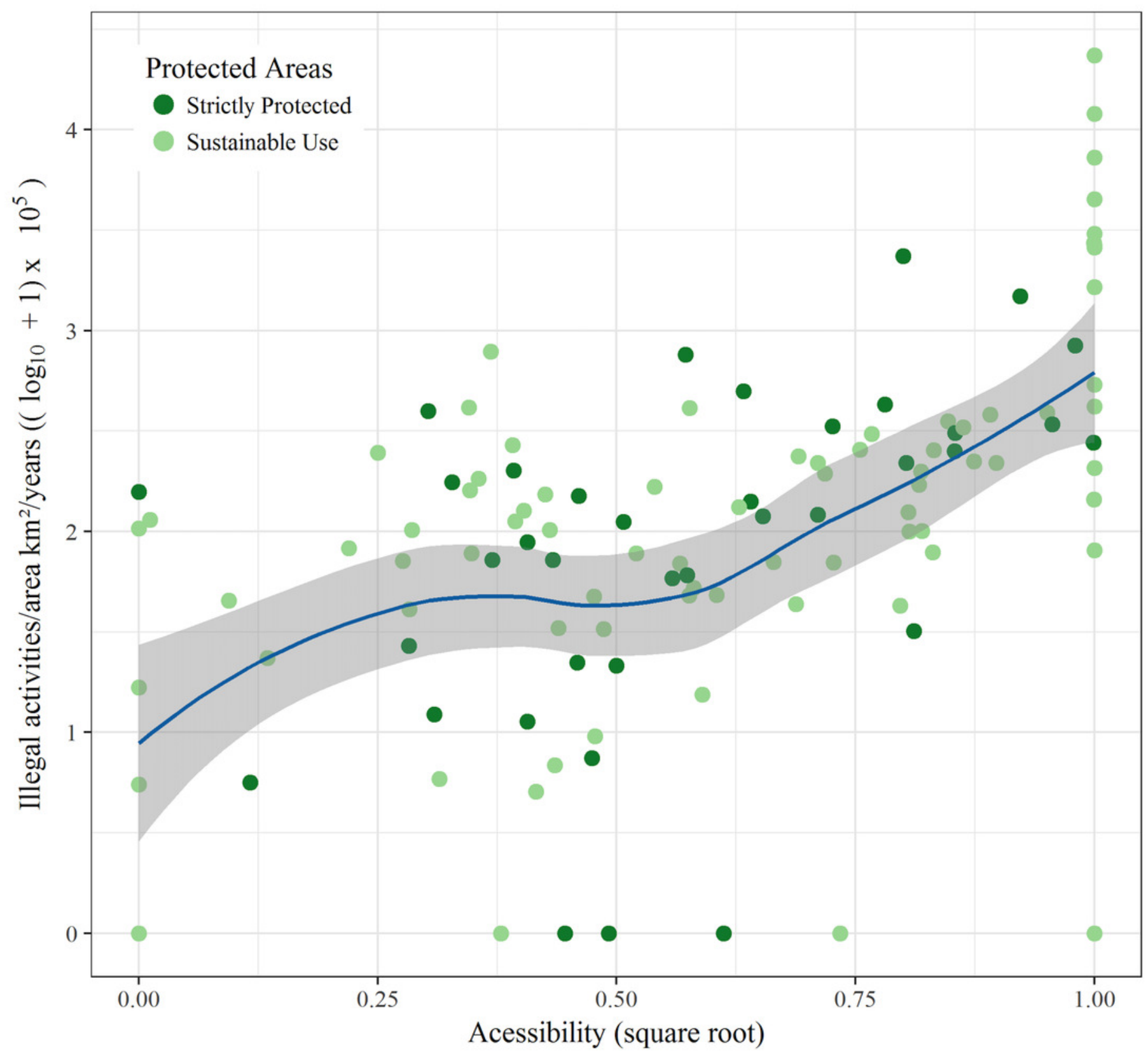




\section{Table $\mathbf{1}$ (on next page)}

Summary of Brazilian Amazon federal protected areas.

Overall information about Brazilian Amazon federal PAs, IUCN category correspondence, absolute number of illegal activities and value of fines. 


\begin{tabular}{|c|c|c|c|c|c|c|}
\hline Protected Area Class & Protected Area Category & IUCN & PAs (n) & Area $\left(\mathbf{k m}^{2}\right)$ & Illegal activities (n) & Fines (U\$) ${ }^{\mathrm{a}}$ \\
\hline \multirow{3}{*}{ Strictly protected } & Ecological Station & $\mathrm{Ia}$ & 10 & $55,248.94$ & 257 & $27,594,947.29$ \\
\hline & Biological Reserve & $\mathrm{Ia}$ & 9 & $36,381.43$ & 963 & $49,005,094.70$ \\
\hline & National Park & II & 19 & $204,324.04$ & 959 & $67,348,814.39$ \\
\hline \multicolumn{3}{|l|}{ Subtotal } & 38 & $295,954.42$ & 2,179 & $143,948,856.38$ \\
\hline \multirow{5}{*}{ Sustainable use } & Relevant Ecological Interest Area & IV & 3 & 189.31 & 6 & $13,573.23$ \\
\hline & Environmental Protection Area & $\mathrm{V}$ & 2 & $20,632.85$ & 5 & $384,154.04$ \\
\hline & Sustainable Development Reserve & VI & 1 & 644.42 & 3 & $10,782.83$ \\
\hline & National Forest & VI & 32 & $164,262.20$ & 901 & $54,675,627.21$ \\
\hline & Extrative Reserve & VI & 42 & $119,250.50$ & 1,149 & $25,613,146.15$ \\
\hline \multicolumn{2}{|l|}{ Subtotal } & & 80 & $304,979.29$ & 2,064 & $80,697,283.46$ \\
\hline \multicolumn{2}{|l|}{ Total } & & 118 & $600,933.71$ & 4,243 & $224,646,139.84$ \\
\hline
\end{tabular}

${ }^{a}$ All fines were imposed in Brazilian real (R\$) and converted to American dollar (US\$) by using an exchange rate of R\$ 3.168: US \$1 for the purpose of comparison with other studies. Dollar quotation on 03/31/2017. 


\section{Table 2 (on next page)}

Generalized additive models (GAMs) results.

Parameter (Slope) estimates of explanatory variables from the GAMs on the number of illegal activities in the Brazilian Amazon federal PAs. 


\begin{tabular}{|c|c|c|c|c|c|c|c|c|}
\hline & \multicolumn{2}{|c|}{ All Illegal activities a } & \multicolumn{2}{|c|}{ Hunting activities b } & \multicolumn{2}{|l|}{ Illegal fishing ${ }^{c}$} & \multicolumn{2}{|c|}{ Flora degradation ${ }^{d}$} \\
\hline & Slope (SE) & t value & Slope $(\mathrm{SE})^{\mathrm{e}}$ & t value & Slope $(\mathrm{SE})^{\mathrm{e}}$ & t value & Slope $(\mathrm{SE})^{\mathrm{e}}$ & t value \\
\hline Intercept & $-1.460(0.521)$ & $-2.80 * *$ & $-0.909(0.577)$ & -1.57 & $-1.718(0.643)$ & $-2.67 * *$ & $-1.318(0.618)$ & $-2.13 *$ \\
\hline $\begin{array}{l}\text { Classes }^{f} \\
\text { (Sustainable use) }\end{array}$ & $-0.160(0.159)$ & -1.00 & $-0.198(0.176)$ & -1.12 & $-0.476(0.197)$ & $-2.42 *$ & $0.163(0.189)$ & 0.86 \\
\hline Age $^{g}$ & $-0.005(0.007)$ & -0.67 & $0.002(0.008)$ & 0.29 & $-0.005(0.009)$ & -0.53 & $-0.009(0.009)$ & -1.02 \\
\hline Accessibility $^{\mathrm{h}}$ & $0.968(0.256)$ & $3.85 * * *$ & $0.502(0.284)$ & $1.77^{\dagger}$ & $0.899(0.316)$ & $2.84 * *$ & $0.527(0.304)$ & $1.73^{\dagger}$ \\
\hline $\begin{array}{l}\text { Population } \\
\text { density }\end{array}$ & $0.574(0.112)$ & $5.14 * * *$ & $0.317(0.124)$ & $2.56^{*}$ & $0.508(0.138)$ & $3.68 * * *$ & $0.449(0.133)$ & $3.39 * * *$ \\
\hline $\begin{array}{l}\text { R-square } \\
\text { adjusted }\end{array}$ & \multicolumn{2}{|c|}{0.391} & \multicolumn{2}{|l|}{0.116} & \multicolumn{2}{|l|}{0.284} & \multicolumn{2}{|c|}{0.194} \\
\hline $\begin{array}{l}\text { Model deviance } \\
\text { explained }(\%)^{1}\end{array}$ & \multicolumn{2}{|c|}{41.20} & \multicolumn{2}{|l|}{14.60} & \multicolumn{2}{|c|}{27.30} & \multicolumn{2}{|c|}{22.10} \\
\hline Model GCVm & \multicolumn{2}{|c|}{0.541} & \multicolumn{2}{|l|}{0.665} & \multicolumn{2}{|l|}{0.826} & \multicolumn{2}{|c|}{0.763} \\
\hline
\end{tabular}

Notes: Significance values: $\dagger \mathrm{p}<0.10,{ }^{*} \mathrm{p}<0.05,{ }^{*} \mathrm{p}<0.01, * * * \mathrm{p}<0.001$; ${ }^{\text {a }}$ Includes the total of all illegal activities (illegal activities/protected area size $\mathrm{km}^{2} /$ number of years) $\log$ transformed $\left(\left(\log _{10}+1\right) \times 10^{5}\right) ;{ }^{\mathrm{b}}$ Includes all hunting activities (hunting activities infractions/protected area size $\mathrm{km}^{2} /$ number of years $) \log$ transformed $\left(\left(\log _{10}+1\right) \times 10^{5}\right)$; ${ }^{\mathrm{c}}$ Includes all illegal fishing (illegal fishing/protected area size $\mathrm{km}^{2} /$ number of years) $\log$ transformed $\left(\left(\log _{10}+1\right) \times 10^{5}\right)$; ${ }^{\mathrm{d}}$ Includes all flora degradation (flora degradation/protected area size $\mathrm{km}^{2} /$ number of years) $\log$ transformed $\left(\left(\log _{10}+1\right) \times 10^{5}\right)$; e Slopes for variables and Standard Error (SE); ${ }^{f}$ Class of protected areas (Sustainable use and Strictly protected); ${ }^{\mathrm{g}}$ Age of protected area creation (creation until 2015) log transformed $\left(\log _{10}\right) ;{ }^{\text {h }}$ Accessibility of protected area square root transformed; ${ }^{\text {i }}$ Population density in a $50 \mathrm{~km}$ buffer from the perimeter of each PA $\log$ transformed $\left(\log _{10} \times 10^{5}\right)$; $\mathrm{k}$-square adjusted for each model; ${ }^{1}$ Percentage of Deviance Explained for each model (\%); ${ }^{\mathrm{m}}$ Generalized Cross-Validation score for each model (GCV). 